Sofia Steinrücke*

Katja Lohmann, $\mathrm{PhD}$ *

Aloysius Domingo, MD

Arndt Rolfs, MD

Tobias Bäumer, MD

Juliane Spiegler, MD

Corinna Hartmann, MD

Alexander Münchau, MD

\section{Neurol Genet}

2016;2:e106; doi: 10.1212/ NXG.0000000000000106

Supplemental data at Neurology.org/ng
NOVEL GNB1 MISSENSE MUTATION IN A PATIENT WITH GENERALIZED DYSTONIA, HYPOTONIA, AND INTELLECTUAL DISABILITY OPEN

Recently, exome sequencing has extended our knowledge of genetic causes of developmental delay through identification of de novo, germline mutations in the guanine nucleotide-binding protein, beta 1 (GNB1) in 13 patients with neurodevelopmental disability and a wide range of additional symptoms and signs including hypotonia in 11 and seizures in 10 of the patients. Limb/arm dystonia was found in 2 patients. ${ }^{1}$

Although the finding of 13 carriers of de novo GNB1 mutations among 5,855 individuals is highly unlikely to be a chance finding, ${ }^{1}$ independent replication of novel disease genes is important ${ }^{2}$ and required for elucidation of the whole phenotypic spectrum, particularly for clinically and genetically highly heterogeneous disorders such as intellectual disability (ID) with currently more than 700 genes implicated in various ID subtypes. ${ }^{3}$

We report a 15-year-old German girl with a de novo GNB1 mutation. She was born as the second child of healthy parents. After normal pregnancy and uncomplicated delivery at term, paucity of movements was first noted at the age of 5 months followed by delayed motor and cognitive milestones. She could walk at the age of 5 and speak a few words around the age of 10 years. Since her early teens, ambulation was impaired and she fell frequently. On examination, she was found to have a slightly triangular but not overtly dysmorphic face. There was ID. Oculomotor testing was normal. Speech production was very limited, and tongue control was impaired. She was generally hypotonic and had generalized dystonia (legs, trunk, neck $>$ arms, and face, figure 1A). She also had intermittent action-induced myoclonus predominantly affecting the trunk, neck, and proximal limb muscles (video at Neurology.org/ng). Reflexes were normal and there were no cerebellar signs. Additional investigations including EEG, MRI/magnetic resonance spectroscopy, and routine blood test, serum copper, ceruloplasmin, amino acids and organic acids in the blood and urine, and CSF investigations including neurotransmitters were also normal. Treatment with levodopa (Madopar; Roche, Vienna, Austria) caused deterioration of dystonia.

Exome sequencing of the patient and her unaffected parents (trio) revealed a heterozygous de novo mutation in GNB1 (c.353A>G, p.D118G, figure $1 \mathrm{~B})$. All 3 family members gave written informed consent, and the local ethics committee approved the design and the use of human subjects for the study. After applying standard filter steps on exome data (table e-1), the de novo mutation in GNB1 and 2 compound heterozygous variants in PTPN13 remained as causative candidate variants. In silico prediction of the pathogenicity of these 3 candidate variants clearly pointed to the GNB1 mutation as disease cause with 3 of 3 tools (PolyPhen-2, SIFT, and MutationTaster) predicting a damaging/pathogenic effect and a Combined AnnotationDependent Depletion (CADD) score of 31, indicating that it belongs to the $0.1 \%$ most deleterious substitutions in the human genome. In contrast, both PTPN13 variants were predicted to be benign/ polymorphisms by PolyPhen-2, SIFT, and MutationTaster and received a CADD score $<10$ (table e-2). The GNB1 missense variant p.D118G was neither found in 186 German controls nor in any of the 60,706 individuals of the Exome Aggregation Consortium (exac.broadinstitute.org/gene/ENSG00000078369).

To further evaluate GNB1 as the causative gene in our patient, we investigated the expression of wildtype GNB1 on the mRNA level in several cell types including induced pluripotent stem cell-derived cortical, striatal, and dopaminergic neurons. A high expression of GNB1 was found in these neuronal cells as well as in the blood and fibroblasts (figure e-1).

GNB1 encodes $G \beta_{1}$, the $\beta$ subunit of a guanine nucleotide-binding protein which forms heterotrimeric complexes with $G$ protein subunits $\alpha$ and $\gamma$. Of note, GNAL, the gene mutated in DYT25 dystonia, ${ }^{4}$ interacts with $\mathrm{G} \beta_{1}$ (consensuspathdb.org). This may provide a link to the dystonic features not only present in our patient but also in 2 recently reported patients. ${ }^{1}$ Of interest, the p.D118G variant and 12 of the 13 previously described mutations are encoded by exons 6 and 7 of GNB1 and cluster in the binding surface for interactions with $\mathrm{G} \alpha$ and various downstream effectors. ${ }^{5,6}$ Interestingly, 2 mutations directly 

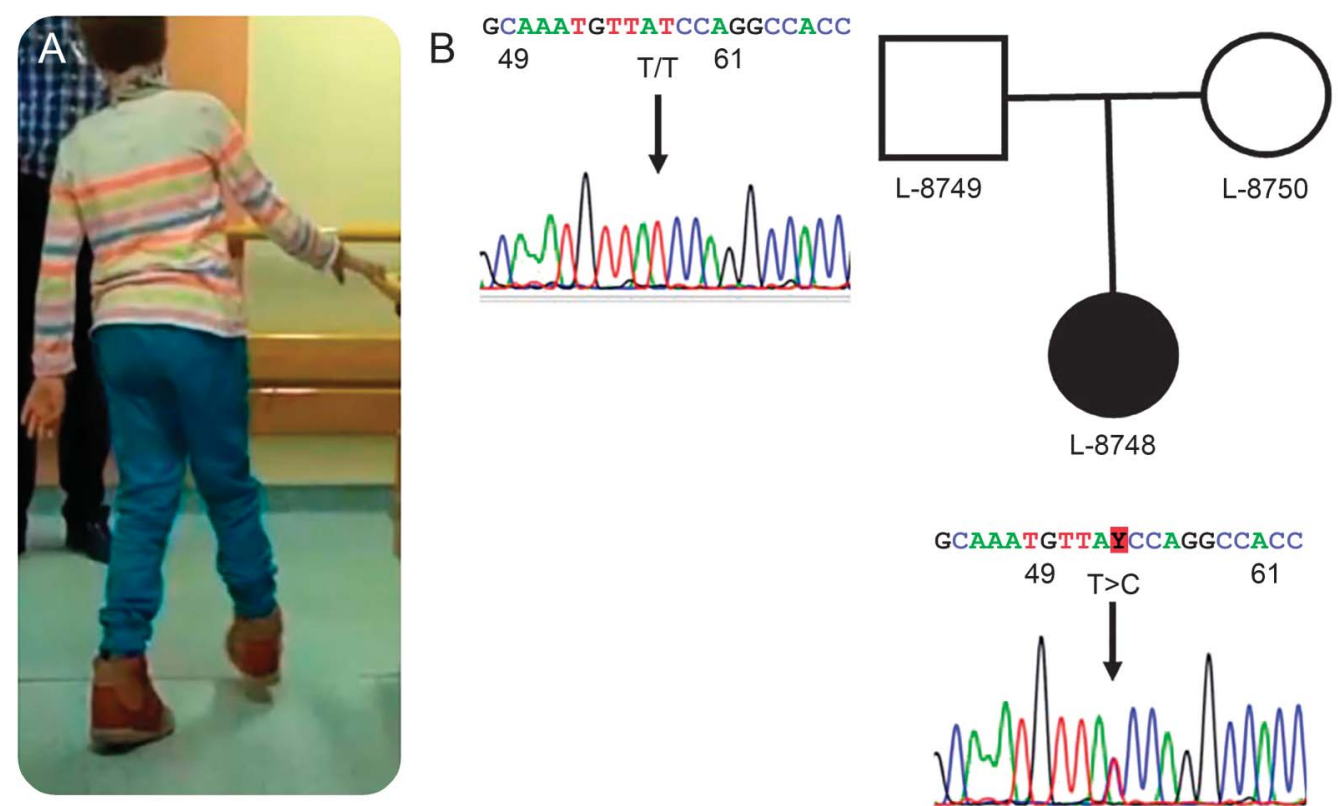

GCAAATGTTATCCAGGCCACC
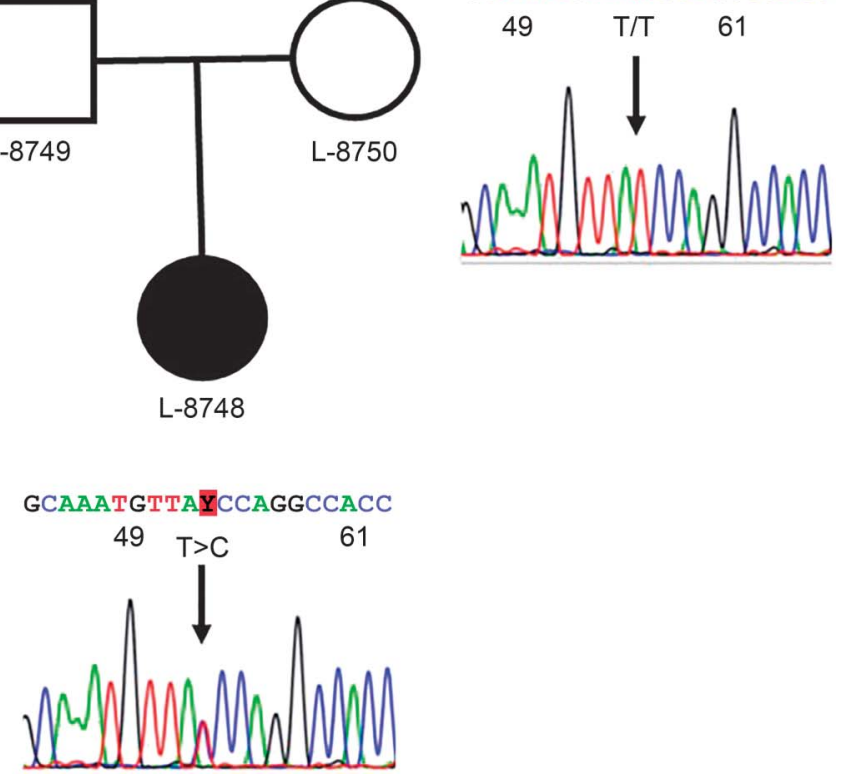

(A) Snapshot of the patient demonstrates dystonic postures of the limbs, trunk, and neck. (B) Pedigree comprises the index patient (filled symbol) and her healthy parents (blank symbols). Results of the validation of the de novo mutation in GNB1 (c.353A >G, p.D118G) by Sanger sequencing on the reverse strand are shown. Both unaffected parents carry 2 wild-type alleles at the respective position (highlighted by arrow), while the affected daughter is a heterozygous mutation carrier.

next to residue 118 , that is mutated in our patient, have been investigated using crystal structural models and shown to alter binding to BARK1 (residue 117) and the inhibition of calcium channels (residue 119). 5,6 These findings strongly support a causative role of the p.D118G variant that may result in altered $\mathrm{G} \beta$ interactions with its effectors.

Our data confirm a pathogenic role of mutations in $G N B 1$, especially within the G $\alpha$-binding surface, as the cause of syndromes with combined developmental delay/ID, hypotonia and, in some cases, dystonia.

* These authors contributed equally to this work.

From the Institute of Neurogenetics (S.S., K.L., A.D., T.B., C.H., A.M.), University of Lübeck; Albrecht-Kossel-Institute for Neuroregeneration (A.R.), University of Rostock; Centogene AG (A.R.), Rostock; and Department of Pediatrics (J.S.), University Medical Center Schleswig-Holstein, Campus Lübeck, Germany.

Author contributions: S.S.: acquisition and analysis of data and drafting a significant portion of the manuscript or figures. K.L.: conception and design of the study, acquisition and analysis of data, and drafting a significant portion of the manuscript or figures. A.D., A.R., T.B., J.S., and C.H.: acquisition and analysis of data. A.M.: conception and design of the study, acquisition and analysis of data, and drafting a significant portion of the manuscript or figures.

Study funding: This work was supported by the German Ministry of Education and Research (BMBF, DYSTRACT consortium, O1GM1514B, to K.L. and A.M.), the Foundation of the University Medical Center Schleswig Holstein "Gutes Tun!" (A.M.), and the Possehl-Stiftung (Lübeck, A.M.).

Disclosure: Ms. Steinrücke reports no disclosures. Dr. Lohmann has been an employee of the University of Lübeck and has received research support from the German Research Foundation and the Dystonia Coalition. Dr. Domingo has received research support from Deutscher Akademischer Austausch Dienst. Dr. Rolfs has received travel support/ speaker honoraria from Shire, Actelion, Biomarin, and Amicus; holds several patents (none are relevant to this manuscript); has been an employee of Centogene AG; has received research support from Shire Human Genetic Therapies; and holds stock/stock options regarding activities as a Centogene AG Management Board member. Dr. Bäumer has served on the scientific advisory board of Merz Pharmaceuticals; has received travel funding/speaker honoraria from Merz Pharmaceuticals, Ipsen Pharma, and Allergan; and has received research support from Ipsen Pharmaceuticals and the Possehl-Stiftung (Lübeck). Dr. Spiegler has received travel funding from Shire. Dr. Hartmann reports no disclosures. Dr. Münchau has received research support from Pharm Allergan, Ipsen, Merz Pharmaceuticals, Actelion, Possehl-Stiftung (Lübeck), the Dystonia Coalition (USA), the Tourette Syndrome Association (Germany), the European Huntington Disease Network, N.E.M.O., Deutsche Forschungsgemeinschaft, and the Dystonia Medical Research Foundation (USA); has received speaker honoraria from Pharm Allergan, Ipsen, Merz Pharmaceuticals, Actelion, GlaxoSmithKline, and Desitin; and has received royalty payments from Oxford University Press. Go to Neurology.org/ng for full disclosure forms. The Article Processing Charge was paid by the University of Lübeck.

This is an open access article distributed under the terms of the Creative Commons Attribution-NonCommercial-NoDerivatives License 4.0 (CC BY-NC-ND), which permits downloading and sharing the work provided it is properly cited. The work cannot be changed in any way or used commercially.

Received July 8, 2016. Accepted in final form August 18, 2016.

Correspondence to Dr. Lohmann: katja.lohmann@neuro.uniluebeck.de

1. Petrovski S, Kury S, Myers CT, et al. Germline de novo mutations in GNB1 cause severe neurodevelopmental disability, hypotonia, and seizures. Am J Hum Genet 2016;98: 1001-1010.

2. Domingo A, Erro R, Lohmann K. Novel dystonia genes: clues on disease mechanisms and the complexities of highthroughput sequencing. Mov Disord 2016;31:471-477. 
3. Vissers LE, Gilissen C, Veltman JA. Genetic studies in intellectual disability and related disorders. Nat Rev Genet 2016;17:9-18.

4. Fuchs T, Saunders-Pullman R, Masuho I, et al. Mutations in GNAL cause primary torsion dystonia. Nat Genet 2013; 45:88-92.
5. Lambright DG, Sondek J, Bohm A, Skiba NP, Hamm HE, Sigler PB. The 2.0 A crystal structure of a heterotrimeric G protein. Nature 1996;379:311-319.

6. Ford CE, Skiba NP, Bae H, et al. Molecular basis for interactions of $\mathrm{G}$ protein betagamma subunits with effectors. Science 1998;280:1271-1274. 


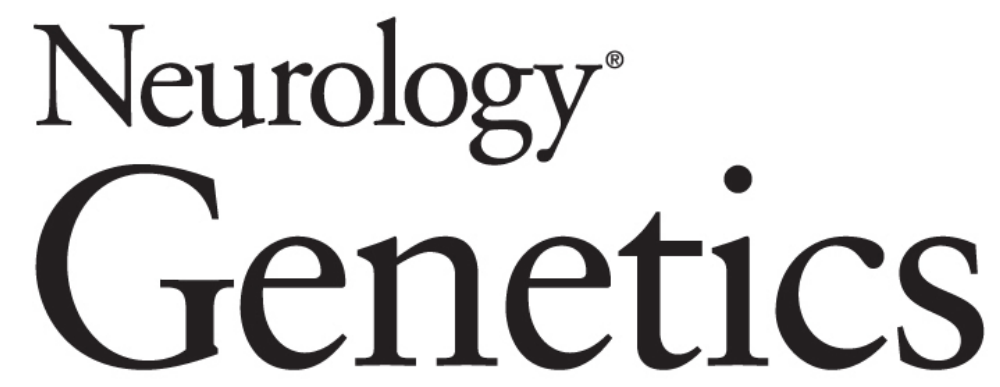

Novel GNB1 missense mutation in a patient with generalized dystonia, hypotonia, and intellectual disability

Sofia Steinrücke, Katja Lohmann, Aloysius Domingo, et al. Neurol Genet 2016;2;

DOI 10.1212/NXG.0000000000000106

This information is current as of September 13, 2016

Neurol Genet is an official journal of the American Academy of Neurology. Published since April 2015, it is an open-access, online-only, continuous publication journal. Copyright ( 2016 American Academy of Neurology. All rights reserved. Online ISSN: 2376-7839.

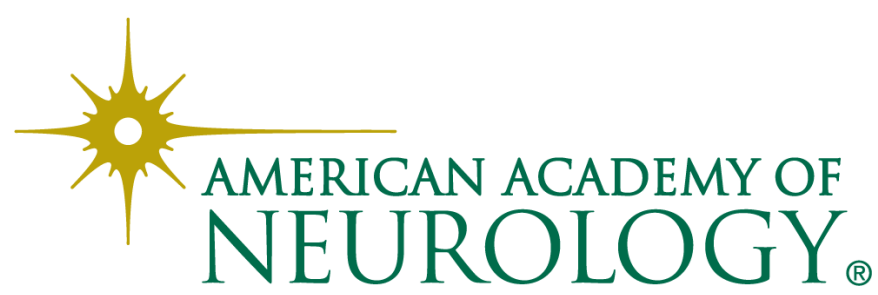




\section{Updated Information \& Services}

\section{Supplementary Material}

\section{References}

Citations

Subspecialty Collections

\section{Permissions \& Licensing}

Reprints including high resolution figures, can be found at: http://ng.neurology.org/content/2/5/e106.full.html

Supplementary material can be found at: http://ng.neurology.org/content/suppl/2016/09/13/2.5.e106.DC1 http://ng.neurology.org/content/suppl/2016/09/13/2.5.e106.DC2

This article cites 6 articles, 1 of which you can access for free at: http://ng.neurology.org/content/2/5/e106.full.html\#\#ref-list-1

This article has been cited by 5 HighWire-hosted articles: http://ng.neurology.org/content/2/5/e106.full.html\#\#otherarticles

This article, along with others on similar topics, appears in the following collection(s):

All Genetics http://ng.neurology.org//cgi/collection/all_genetics

Developmental disorders

http://ng.neurology.org//cgi/collection/developmental_disorders Dystonia

http://ng.neurology.org//cgi/collection/dystonia

Mental retardation

http://ng.neurology.org//cgi/collection/mental_retardation

Information about reproducing this article in parts (figures,tables) or in its entirety can be found online at:

http://ng.neurology.org/misc/about.xhtml\#permissions

Information about ordering reprints can be found online: http://ng.neurology.org/misc/addir.xhtml\#reprintsus

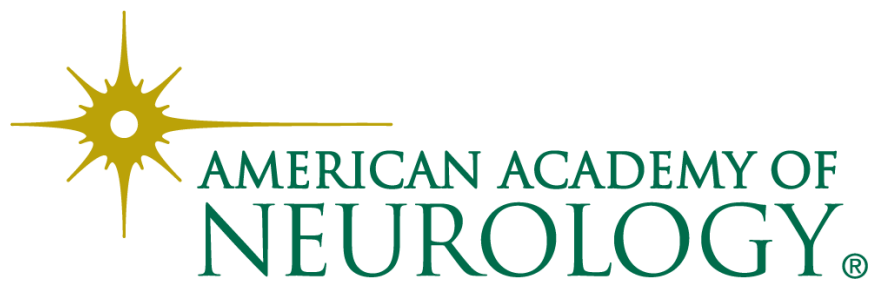

